\title{
Is maatwerk willekeur?
}

\author{
Jaap van Dooren
}

\author{
Het UWV ging aan de slag met lastige casussen die niet in 'het systeem' \\ passen. De standaardoplossing heeft dan niet het resultaat zoals \\ beoogd door de betreffende wet of regeling en de burger kan onbedoeld \\ benadeeld worden. Aan de hand van de casus van Saskia beschrijft \\ Jaap van Dooren de dilemma's die daarbij spelen in de organisatie en \\ de uiteindelijke maatwerkaanpak.
}

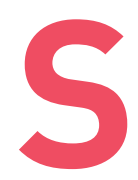

askia heeft een slechte jeugd.' Zij groeit op in een gezin met ruzie en geweld. Wanneer haar ouders uit elkaar gaan verslechtert de relatie van Saskia met beide ouders. Als puber zoekt Saskia 'foute vrienden' en valt zij uiteindelijk in handen van een loverboy.

Wanneer Saskia een dochter krijgt, wil zij toch haar leven in rustiger vaarwater krijgen. Zij heeft forse schulden en de zorg voor haar dochter als alleenstaande jonge moeder valt haar zwaar. Zij gaat werken, maar het lukt haar niet om een baan te houden. Wanneer zij hulp zoekt blijkt dat er sprake is van zowel psychische als psychiatrische problematiek en Saskia komt in aanmerking voor een Wajong-uitkering. Saskia gaat in therapie.

Wanneer er weer enige regelmaat is in haar leven wil zij weer werken, mede om haar forse schulden te kunnen aflossen.

In 2013 heeft Saskia naast haar Wajong-uitkering inkomsten uit werk. Maar zij geeft deze inkomsten uit werk niet door, volgens het UWV. Saskia geeft aan dat zij haar situatie telefonisch heeft doorgegeven, maar dat is niet terug te vinden in haar dossier. In deze periode (2013) deelde het UWV hoge boetes uit: ongeveer even hoog als de vordering. De totale schuld van Saskia aan het UWV is daardoor ongeveer $€ 30.000$ (navordering en boete). Daarnaast heeft Saskia nog de andere schulden. Doordat er 'fraude' is gepleegd kan Saskia niet deelnemen aan een schuldsaneringsregeling conform de Wet schuldsanering natuurlijke personen (WSNP). De consequentie is dat zij minimaal acht jaar haar schulden aan het UWV aan het aflossen is en gedurende die periode op het bestaansminimum leeft met haar dochtertje. Een paar jaar later wordt zij voor de Wajong ingedeeld in klasse DGA, 'duurzaam geen arbeidsvermogen'. Dit betekent dat zij geen re-integratie-ondersteuning kan krijgen maar wel een iets hogere uitkering (75 procent van het sociaal minimum, anders 70 procent).

Saskia's verhaal is een verhaal van vallen en weer opstaan. Moeilijke omstandigheden, problematische schulden, beperkte steun vanuit haar omgeving en een jong kind. Het werken in een 'normale omgeving' lukt ook niet gelijk. Gelukkig kan zij wel terugvallen op haar uitkering.

In dit soort casuïstiek reageren de meeste collega's geschokt en vinden zij de situatie voor Saskia heel vervelend. We zien allemaal dat dit vraagstuk volgens standaardprocedures niet op te lossen lijkt. Maar vervolgens leggen we elkaar ook haarfijn uit waaróm de werking van wetten en regels zo is en waarom dit zo loopt. Met de conclusie dat we niet voor elke uitzondering een oplossing kunnen bedenken, want daarmee creëer je willekeur en precedentwerking. Heel soms zijn er mensen - met meer mandaat - die voor deze ene casus wel een uitzondering willen maken, maar dan geldt deze niet voor anderen in een vergelijkbare situatie. 'Heel vervelend voor Saskia, dikke pech, maar niks aan te doen', is dan de eindconclusie.

Deze casus staat niet op zichzelf, er zijn vele Saskia's. Met vooral één gemene deler: er is geen standaardoplossing en deze mensen lopen vast in 'het systeem'. 


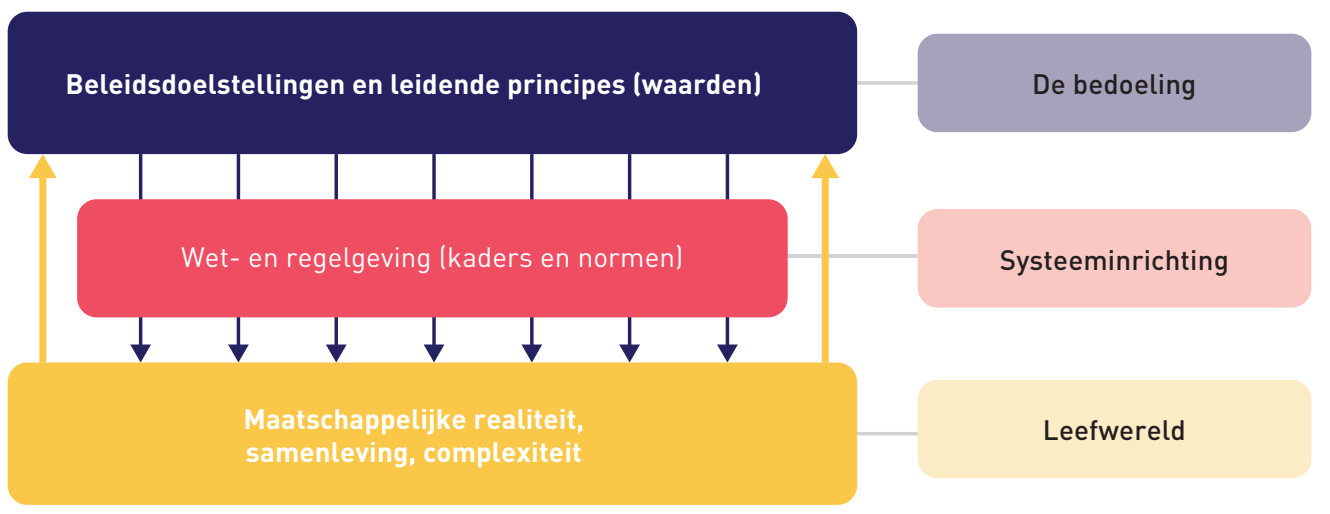

Figuur 1. Schematische weergave van de drie omgevingen waarin het UWV opereert.

\section{Waarden, systeeminrichting en leefwereld} 'Het systeem'? Wat wordt hier nu mee bedoeld? We hebben bij het UWV een schema ontwikkeld om dit duidelijk te maken (zie figuur 1).

Het bovenste vlak bestaat uit de opgave (missie) van onze organisatie en uit de leidende principes (bedoeling) van de wetten die we uitvoeren, zoals de Participatiewet en de Wet Wajong waar Saskia mee te maken heeft.

Het middelste vlak staat voor de systemen die we gebruiken om de wet en haar bedoeling te kunnen uitvoeren. Door middel van wetten, regels, beleid, instructies, systemen, et cetera maken we de systeeminrichting. Volgens deze systeeminrichting krijgt Saskia lingedeeld in Wajong DGA) bepaalde dienstverlening wel en andere niet. Volgens dezelfde systeeminrichting krijgt zij ook een terugvordering en een even hoge boete, met als gevolg geen recht op schuldsanering (WSNP).

Het onderste vlak staat voor de praktijk waarin de burger en de werkgever zich bevinden (de leefwereld). In ongeveer tachtig procent kunnen wij als organisatie en onze vakmensen uit de voeten met de kaders en de richtlijnen (de systeeminrichting) en kunnen we de burger en maatschappij goed bedienen. Het 'systeem' werkt dan zoals het is bedoeld. Maar voor circa twintig procent lukt dit niet, waardoor de burger en/of de maatschappij (in geval van fraude bijvoorbeeld) onbedoeld benadeeld kunnen worden. Daar waar dat niet lukt moet maatwerk worden toegepast. De maatschappelijke opgave is hier het kader. Zo zou het bij Saskia ook moeten.
Het omgaan met die naar schatting twintig procent vinden we heel erg moeilijk. Elke keer grijpen we terug op het bekende, de systeeminrichting. Alleen vinden we daar nu net niet het antwoord voor deze persoon in deze situatie.

Hiervoor zijn vakmanschap van onze medewerkers en werkende methodieken om maatwerk toe te passen nodig maar ook een meer opgavegerichte manier van sturen.

\section{Maatwerk in de praktijk}

De afgelopen jaren zijn we bij het UWV aan de slag gegaan met dit soort maatwerkvraagstukken. Hoe ga je om met vraagstukken waar de systeeminrichting geen passend antwoord heeft?

We hebben methodieken ontwikkeld en geleend van andere organisaties om maatwerk te kunnen toepassen, vanuit het principe 'ongelijke gevallen in gelijke mate ongelijk behandelen'. Daarnaast hebben we een netwerk opgericht waarmee en waarbinnen we presentaties en workshops houden in het hele land, zowel binnen als buiten het UWV. Hier delen we kennis en praktische wijsheid door concreet aan de slag te gaan met casuïstiek. Zo hebben we onder andere sessies georganiseerd rondom het WRR-rapport Weten is nog geen doen en het Algemene Bestuursdienst-rapport Regels en Ruimte. Verkenning Maatwerk in dienstverlening en discretionaire ruimte.

In Utrecht is er een 'Lichtpunt' opgericht. Een groep medewerkers van de verschillende afdelingen bespreekt hier ingewikkelde casuïstiek en probeert deze natuurlijk ook op te lossen. Ook is 
er in Apeldoorn een WIA-team ontstaan dat de afdelingsstructuren heeft losgelaten en waarvan de teamleden allemaal op één verdieping bij elkaar zitten om zo de burger beter te kunnen bedienen. Ook hierbij komen maatwerkvraagstukken naar voren die zij gezamenlijk nu makkelijker kunnen oppakken en oplossen. De kern van de aanpak is oplossingsgerichtheid: hoewel aanpakken van deze initiatieven mogelijk anders zijn, werken zij allemaal opgavegericht, zij gaan op zoek naar 'hoe de wet(geving) bedoeld is' en of dat dan ook wordt bereikt in de specifieke casus. Hiermee ontdekten we dus ook dat 'standaard dienstverlening' (de circa tachtig procent) in complexe vraagstukken - bijvoorbeeld bij levensgebeurtenissen of bij stapeling van verschillende wetten - niet de uitkomst geeft zoals vanuit de wet bedoeld was.

De Participatiewet heeft als bedoeling 'iedereen doet mee', de bedoeling van de Wet boeten, maatregelen en terug- en invordering sociale zekerheid (Wet BMTI) is terugdringen van oneigenlijk gebruik en de WSNP kent als bedoeling het tegengaan dat mensen jarenlang door hun schulden achtervolgd worden.

Bij Saskia is sprake van een stapeling van wetgeving met verschillende 'bedoelingen':

Participatiewet, Wet BMTI en WSNP, waarbij we drie wetten keurig uitvoeren met een desastreuze uitwerking voor Saskia. We zagen dat de situatie voor zowel Saskia als de betrokken collega's inmiddels volkomen onbegrijpelijk was geworden. Medewerkers van de afdelingen handhaving en invorderen hadden een volstrekt andere opgave dan medewerkers van de afdeling werk (re-integreren). En iedereen wilde vooral zijn eigen opdracht goed uitvoeren en wordt ook op die opdracht aangesproken. Als medewerker is het continu manoeuvreren op het spanningsveld efficiency versus maatschappelijke opgave. Een medewerker moet ook productietargets halen en ingewikkelde casuïstiek levert productieverlies op.
Daarnaast zagen we het calimero-effect verrassend vaak voorbijkomen. Wanneer er maar één persoon in de problemen komt dan is dat vervelend voor die ene persoon, pas wanneer er 'massa' ontstaat lijken we er serieus mee aan de slag te gaan. Deze efficiencyaanpak is natuurlijk volkomen begrijpelijk: liever tien dossiers per uur afgehandeld dan één dossier per dag. Maar voor die ene persoon kan onze aanpak wel of niet doorslaggevend zijn voor een verbetering in de situatie. De les die we hieruit halen is dat we het no one left behind-principe moeten toepassen. Daarbij zetten we in op een overheid die iedere burger passende dienstverlening biedt. En niet alleen voor een selecte groep, want dan zou er sprake zijn van willekeur.

\section{We hebben methodieken ontwikkeld vanuit het principe ongelijke gevallen in gelijke mate ongelijk behandelen'}

\begin{abstract}
Maatwerkplaats
Inmiddels zijn we in de volgende fase beland: de maatwerkaanpak. Het UWV gaat inzetten op de realisatie van maatwerkplaatsen, waarin we ons richten op specifiek maatwerk zoals in het geval van Saskia. De maatwerkplaatsen richten zich op het verbinden van bestaande kennis, vaardigheden en methodieken, en daarnaast op snelle oplossingen voor casuïstiek die anders (te) lang blijft liggen. Het ultieme doel is om maatwerk bij het eerste contact met de burger goed te organiseren. Wanneer wordt gestuurd op deze opgave en medewerkers in de frontlinie voldoende uitgerust zijn om dit zonder willekeur te kunnen doen, is dit doel bereikt. Tot we zover zijn gebruiken we de maatwerkplaats(en) als steunstructuur.
\end{abstract}

\section{Inkijkje in de ontwikkelde methodieken}

We hanteren het fix and solve-principe: we lossen het knelpunt op voor die ene burger en we kijken tegelijkertijd of er structureel dingen anders moeten in onze interne organisatie, dan wel in de weten regelgeving. Dit doen we door alle casussen te verzamelen, inclusief de eventuele oplossingen. Dit noemen we casusprudentie. 


\section{We voorkomen dat burgers alleen door middel van klachten- en bezwaar- procedures alsnog passende dienstverlening krijgen}

We werken multidisciplinair om een goed afgewogen besluit te nemen. Dit betekent dat we met diverse functionarissen van diverse afdelingen vanuit gelijkwaardigheid de casuïstiek bespreken, met de burger en de bedoeling van de wet(ten) als uitgangspunten.

We gebruiken hier vaak de perspectiefcirkel bij, waarmee een willekeurige afslag wordt voorkomen.

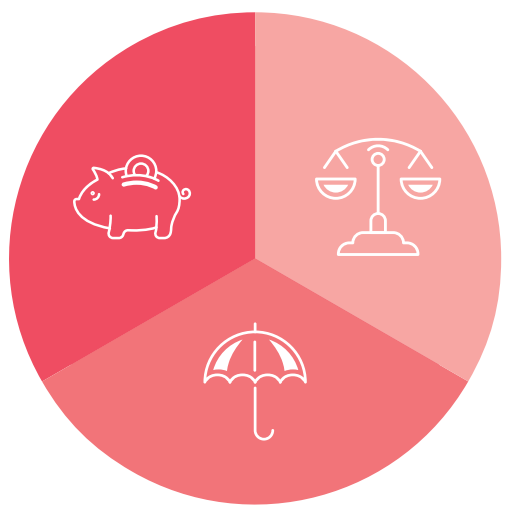

Figuur 2. De perspectiefcirkel. Het spaarvarkentje staat voor het financieel/economische perspectief, de weegschaal voor het juridische perspectief en de paraplu voor het maatschappelijke/ burger-perspectief

Met dit soort ondersteunende methodieken wordt het gewoonte om meerdere perspectieven mee te wegen in de beoordeling van een casus zoals die van Saskia vanuit vragen als:

- Wat is de financiële uitkomst van de optelsom van de terugbetaling van de boete als vordering op de (langdurige) uitkering, en welk effect heeft dit op de terugkeer van Saskia in werk?

- In hoeverre botst de bedoeling van de Participatiewet (iedereen doet mee) met deze uitkeringsstatus - zonder re-integratiemogelijkheden - en een uitzichtloze schuldenstapeling?

- Wat is de mogelijke impact op de dochter van Saskia als zij met schulden opgroeit? Zijn hierover ook wetenschappelijke inzichten?
Op deze manier kijken we in een multidisciplinaire setting van collegae luitvoeringsdeskundige, jurist, beleidsmedewerker, manager) naar oplossingsrichtingen. Voor Saskia en ook voor anderen die in exact dezelfde situatie zitten. Zo voorkomen we willekeur. Om terug te komen op onze startvraag 'is maatwerk willekeur?': nee, maatwerk is dus géén willekeur. Het is het geobjectiveerd passend handelen in situaties waarin de gangbare toepassing van regels zou leiden tot een onrechtvaardige uitkomst in strijd met de bedoeling van de wetgever. En zo voorkomen we dat burgers alleen door middel van klachten- en bezwaarprocedures alsnog passende dienstverlening krijgen.

Naast UWV-maatwerkplaatsen wordt er door een aantal ministeries ook ingezet op een rijksbrede maatwerkplaats, waarin organisatie- of domeinoverstijgende vraagstukken sneller en met de juiste experts worden opgelost. En waarin ook met korte lijntjes kan worden gewerkt wanneer er structurele aanpassingen in wetgeving of beleid moeten worden georganiseerd. Alle bestaande methodieken en casusprudentie worden hier verzameld, zodat iedereen hier gebruik van kan maken.

\section{Saskia tot slot}

En hoe is het nu met Saskia? Saskia krabbelt langzaam op. Eind 2019 was het vijf jaar geleden dat zij de terugvordering en de boete kreeg van UWV. Na vijf jaar verliest zij het stempel 'fraudeur', komt zij in aanmerking voor een minnelijke schikking en kan zij de schuldsanering in. Dit betekent nog drie jaar op bestaansminimum leven en dan is zij schuldenvrij. Daarnaast heeft Saskia al jaren ondersteuning van een arbeidsdeskundige van het UWV die haar begeleidt naar werk. Het gaat beter met Saskia. Zij heeft zelfs al een keer met ons op het podium gestaan tijdens een congres om haar verhaal te doen. Een flinke overwinning. De casus Saskia kreeg geen snelle, pasklare oplossing en is een belangrijke drijfveer om in complexe situaties meer maatwerk te kunnen leveren.

\section{Noot}

1 De naam Saskia is uit privacyoverwegingen gefingeerd.

$J$. van Dooren is manager Kwaliteit van de divisie Werkbedrijf van het UWV en een van de initiatiefnemers van het publieke netwerk 'werken vanuit de Bedoeling'. 